\title{
Russians' Attitude to Distance Learning: a Runet Survey
}

\author{
Gennadi B. Pronchev, Inna V. Goncharova and Konstantin G. Pronchev \\ Lomonosov Moscow State University \\ Moscow, Russia \\ Eugene I. Krichever \\ National Research University "Higher School of Economics" \\ Moscow, Russia
}

\begin{abstract}
The objective of this work is to study the Russians' attitude to distance learning based on contemporary information and communication technologies. The methodological basis of the research is the use of analytical services of the Internet for studying the Russians' online activity. As an empirical basis, the work employs two Internet studies conducted by the authors in 2018 and 2019, and it analyzes the interest of the Runet [Russian network] users in the online form of knowledge acquisition. In recent years, the growth of interest in distance learning has been noted with individual seasonal drops. There is a trend to get higher education with state-recognized degrees and formally awarded qualifications. In Russia, schoolchildren of grades 10-11 extensively use online social networks to improve the efficiency of training in mathematics. They prefer Internet communities adhering to the traditional teaching principles. A combination of educational and entertaining content attracts a larger quantity of users. The results of the research are of interest for specialists dealing with the problems of distance learning and sociology of education.
\end{abstract}

Keywords: Distance Learning; the Internet; Statistical Services; Social Networks; Mathematics.

\section{Introduction}

According to the International Telecommunication Union, at the end of 2018, the global Internet network was accessed by 3,9 billion people or $51,2 \%$ of the planet's population (ITU, 2018). According to the results of the All-Russian representative survey (telephone interview, 3200 respondents aged 18 and older) conducted by VCIOM [All-Russian Center for the Study of Public Opinion] on September 24-25, 2018, the percentage of Internet users in Russia amounts to 
$81 \%$ of the surveyed ones. Among them, $65 \%$ go online almost every day (VCIOM, 2018).

As a result of the upgrade of the Russian school, information and communication technologies have become an integral part of the educational process. At the same time, the main requirement for the way learning is organized has remained adherence to the educational principles and technological practices as applied to the traditional instruction format: lectures, practical classes, independent work, etc. (Goncharova et al., 2017).

The development of Web technologies and propagation of the global Internet network contribute to the creation of new kinds of interaction between the participants of the educational process and to the development of new virtual educational environments (Pronchev, 2013; Pronchev et al., 2015; Chigisheva, 2018). New learning forms have come to take the place of traditional distance learning.

Studies conducted among distance learning teachers and tutors (in-person interviews, telephone interviews, e-mail surveys) (Pekker, 2015) have shown that the experts consider the following advantages. They mention a flexible learning, opportunity to get instruction at any point of the world, acceptable cost of education (cheaper than intramural learning mode), and opportunity of supplementing the intramural learning mode. Meanwhile, they outlined main disadvantages of distance learning, too. These included uncertain role and place of the distance learning in Russia, lack of levers of influence over uninterested learners, shifts of learning objectives from supplying the knowledge to involving the students. Another disadvantage is a large number of students, so the teacher has no physical possibility to spare the required time for everyone. Nevertheless, the experts give a positive forecast concerning the development of distance learning in Russia. They note that "Distance learning is going to develop fast" and "In ten years it will become an efficient form of learning" (in Pekker, 2015, p. $67)$.

This work deals with studying the interest of the Runet [Russian network] users in the distance form of knowledge acquisition. Using social networks as an example, we analyze the possibility of improving the efficiency of school students' training in mathematics.

\section{Literature Review}

Rapid technological development of the second half of the 20th century made the question of introducing new standards for educational processes relevant. So, the American researcher, futurist Richard Buckminster Fuller (1962), pointed to the fact that the future education will turn into the vital sphere in the rank of the world's most significant industries. This process will contribute to the development of information technologies.

The American philosopher and sociologist Alvin Toffler (1971) wrote: 


\begin{abstract}
"In the technological systems of tomorrow - fast, fluid and selfregulating - machines will deal with the flow of physical materials; men with the flow of information and insight. ... Human work will move out of the factory and mass office into the community and the home. ... For education the lesson is clear: its prime objective must be to increase the individual's "cope-ability" - the speed and economy with which he can adapt to continual change. And the faster the rate of change, the more attention must be devoted to discerning the pattern of future events" (in Toffler, 1971, p. 402). "With information becoming more important than ever before, the new civilization will restructure education, redefine scientific research" (in Toffler, 1980, p. 368).
\end{abstract}

Accordingly, the author noted developing his "Third Wave" concept.

Another American sociologist, Daniel Bell (1980), proposed a reorganization of education based on computer learning and the vast propagation of video disks. In his major work, "The coming of post-industrial society: A venture of social forecasting" he pointed out that the growth of technical needs and professional mastery renders education, and, in particular, the access to higher education, a condition of the very entry into the post-industrial society (Bell, 1973).

The Spanish sociologist Manuel Castells (1996) notes that the nearest future will see the use of computer-based communication expand, primarily via the system of education, and cover an essential share of the population of the industrial world. It will cease to be an exceptionally elite phenomenon even though it will cover much fewer people than the mass media do. Meanwhile, the researcher points to the fact that the classrooms will hardly dissolve in the virtual environment. In the case of primary and secondary schools, the matter is they are both childcare centers/shelters for children and educational institutions. In the case of universities, this takes place because the quality of education is still associated with and for some more time should be related to intensive face-toface interaction. Thus, the large-scale experience of extramural universities, regardless of their quality (which is deficient in Spain and excellent in the UK), shows that this is a form of education chosen by people if they cannot study at the traditional universities. Such structures could play a significant part in the future, a better system of education for adults, but they will hardly be able to replace today's higher educational institutions (Castells, 1996).

The Russian researcher Gennadi Pronchev (2013) notes the contemporary information and communication technologies allow creating new kinds of interaction between participants of the educational process and unique educational, social environments with preset properties. The use of digital educational settings at general educational schools improves the efficiency of the learning and upbringing process. The availability of various resources enables teachers to vary the process of learning, to use combined lessons, to organize education for people having health limitations thus leveling out the social inequality emerging and socializing the people up to the contemporary Russian society (Pronchev et al., 2017; Pronchev et al., 2018). Alongside the direct organization of the process of learning, digital educational, social environments 
enable pedagogical workers to demonstrate the most significant results of their practical activities for assessing their professional competence (Pronchev et al., 2015).

By the end of the 20th century, the main provisions of the development of education in the 21st century were worded in the scientific thought; among them, there were the digitization of education, IT-penetration, and propagation of distance learning (Kirkwood, 2014; Dillenbourg, 2016).

In the contemporary academic discourse, they also analyze the problem of ITpenetration in education and distance learning in particular. The well-known Russian philosopher Vladimir Mironov (2019) welcomes the opportunity of using the contemporary information technologies in the educational process; however, he outlines some negative consequences of the complete rejection of the intramural mode of learning:

"We can consider online education as an additional form, and we have to make use of it. But there is a purely technical side to it, too... If we do speak about the high-level online education, then we have to use the computer - I beg your pardon - not as a hammer for driving nails in, but taking into account all the opportunities of the PC itself and the Internet space to enhance a constituent of this education. First of all, this is the information side; it can also be about displaying visual images. Certainly, there are lots of opportunities for using supplementary things, but anyway, I think, online education has to be yet the additional one" (in Mironov, 2019, p. 12).

The well-known Russian scientists Ilya Iliyn and Arkady Ursul (2016) note:

"As a result of IT-penetration, a qualitatively new system of continuous, open, and flexible distance education will be created, which, to a significant extent, will help to overcome the crisis of education. However, we can voice doubts as for the information society in its "Western version" to be free from disadvantages and automatic solution of all problems, particularly in their global change. For the information society to play its positive part, it is vital to input the necessary humanist content into the new information technologies and artificial intelligence systems. This is something the present-day spontaneous "Western pattern" process of IT-penetration clearly lacks" (in Ilyin \& Ursul, 2016, p. 22).

Thus, as early as at the beginning of the second half of the previous century, a higher interest in transforming education based on the development of information technologies and the creation of new virtual educational environments can be noted. However, at present, the representatives of the academic sphere increasingly more often speak about the necessity of taking a sensible approach to distance learning, with the value of personal contact of teachers and students borne in mind. 
H.F. Haba and O. Dastane (2019) analyzed two virtual educational environments, i.e., Coursera (40 million learners) and edX (14 million learners) using Massive Open Online Courses (MOOCs) as a learning environment. Eight aspects were studied: convenience of learning, course diversification, ease of use (including performance platforms), learner experience, monetary aspect, pedagogy aspect, quality, and support for learners. Almost every element received negative comments from users. The noted shortcomings clearly impede the even greater spread of virtual educational environments among consumers.

It should be noted that in modern academic scientific discourse, little attention is paid to the assessment of negative consequences that brings computerization of education. In our work (Pronchev et al., 2019), we analyze and classify information threats that arise in the virtual media environment. New threats lead to the change in social reality and the transformation of interaction models in it. We propose the mechanisms to counter emerging threats. One of the most important ones is to increase the level of users` education from both technical and humanitarian viewpoint (Pronchev et al., 2019). Another critical aspect, little reflected in modern research, and that this paper much contributes to, is the analysis of users' attitudes to distance learning in Russia, changes in users interest depending on various factors.

The originality and novelty of this work consists in the attempt to analyze the "seasonal" dynamics of users` audience in virtual educational environments, as well as the factors affecting their popularity.

\section{Methodological Framework}

The objective of this research is studying the Russians' attitude to distance learning.

The main tasks of the research were to analyze:

- the interest of the Runet [Russian network] users in the distance form of knowledge acquisition;

- the possibility of using social networks for improving the efficiency of school students' training in mathematics.

As the empirical data source for this work, we use two Internet studies conducted by us in 2018 and 2019.

When conducting the Internet studies, we worded the hypothesis about there being a stable and significant statistical association between the intensity of the Internet users' search queries in search engines (descriptors) and the selected events display level (indicators) (Petrov \& Pronchev, 2017).

Identification of the main definitions, problems, properties, and the range of tasks of the distance learning in the Russian society allowed singling out the sign words and fixed phrases (descriptors) input by users for searching for the information they need with a search engine. We compiled two descriptor dictionaries for the Internet research. A detailed procedure for compiling 
dictionaries is given in our work (Petrov \& Pronchev, 2017). The frequency of descriptor users` requests was analyzed using commercial statistical services.

The first study analyzes the popularity of distance learning with the Russians.

We used the free statistical service "Yandex. Keywords selection" as a research tool. It provides statistics on a descriptor (or several descriptors) input by the user. As a rule, a particular search request was used as a descriptor; however, the service also offers a set of so-called "topics" that are, in fact, collections of claims. The statistics have the appearance of a temporal row of points representing indicators of the quantity of queries on different days. The technology is described in more detail in our work (Petrov \& Pronchev, 2017).

The second study was dedicated to analyzing the possibility of using social networks on the Internet to improve the efficiency of school students' training in mathematics. As the toolkit, the Popsters analytical service was used. The academic year of 2018-2019 was investigated for the involvement of subscribers and identification of the most popular content etc. according to semesters of the academic year.

\section{Results and Discussion}

Two studies were conducted to determine the attitude of Russians towards distance learning. The first study provided the analysis of the number of Internet requests of Russians about distance learning, depending on the time. This helped to come to a conclusion about the popularity of this topic among users. "Seasonal fluctuations" and the most popular Internet resources and users' preferences were identified. In the second study, using the example of mathematics distance learning, the factors that attract users to specific Internet resources were analyzed.

\subsection{The Analysis of the Quantity of the Russians' Online Requests about the Distance Learning}

The analysis of the segment of statistical data about the selected descriptors requested for the period from 2016 to 2018 has shown that there is nonuniformity of the absolute and relative values, with growth traced over time with individual seasonal drops in the activity of impressions (queries). For impressions of the "distance learning" phrase, the absolute maximum quantity of 2016 amounts to 230629, the figure was significantly higher in 2017 - 275641, with peaks falling for October, and minimum ones recorded in July: 146735 in 2016 and 151584 in 2017 (Goncharova et al., 2018).

Meanwhile, the relative index showing the popularity of the request among all others equals 0,000035111356. For comparison purposes, the highest relative indicator of the "education" keyword query recorded in the latest two years makes 0,001407673906 (Goncharova et al., 2018).

Variants of prompts for inputting the word combination "distance learning" in Yandex. Keywords selection search window displayed as hints during typing the phrase 
include notions "distance training," "distance learning at a higher educational institution," "distance learning at school," with various indices of impressions per month.

Selection of 10 phrases provided by Yandex. Table 1 shows the keywords selection graded according to the result and maximum quantity of impressions per month for years 2016-2018.

Table 1: Descriptor counts of requests by Runet [Russian network] users

\begin{tabular}{|l|c|c|}
\hline \multicolumn{1}{|c|}{ Descriptors } & \multicolumn{1}{|c|}{$\begin{array}{c}\text { Results of the } \\
\text { impressions }\end{array}$} & $\begin{array}{c}\text { Impressions } \\
\text { per month }\end{array}$ \\
\hline Distance learning & 38 million & 274000 \\
\hline $\begin{array}{l}\text { Distance learning at the state higher } \\
\text { educational institution in Moscow list }\end{array}$ & 158 million & 7560 \\
\hline Distance learning higher education & 86 million & 7470 \\
\hline $\begin{array}{l}\text { Distance learning ASM (Academy of } \\
\text { Social Management) }\end{array}$ & 177 million & 471 \\
\hline Distance learning is... & 104 million & 2527 \\
\hline Distance learning at school & 83 million & 3212 \\
\hline $\begin{array}{l}\text { Distance learning RSUH } \\
\text { (Russian State University for the } \\
\text { Humanities) }\end{array}$ & 36 million & 1761 \\
\hline $\begin{array}{l}\text { Distance learning VLSU } \\
\text { (Vladimir State University) }\end{array}$ & 27 million & 2157 \\
\hline $\begin{array}{l}\text { Distance learning RSREU } \\
\text { (Ryazan State Radio Engineering } \\
\text { University) }\end{array}$ & 31 million & 525 \\
\hline Distance learning in IT & 53 million & 191 \\
\hline
\end{tabular}

Source: authors based on Goncharova et al., 2018.

The interest shown by users of the Runet [Russian network] in getting higher education with state-recognized degrees and a qualification awarded formally (29182 queries in January 2018) is not unfounded. This opportunity was legislated by Federal Law No. 273-FL (2012) in which the notion of distance learning and norms of its use are detailed. This way is adopted, for example, at Synergy University that launched its own virtual platform Synergyonline. Various devices support the platform, and it ensures access to educational courses from any point in the world at any time. Each student has his or her "Personal account" via which they manage and access multi-format study materials, interactive tests, video lectures, seminars, and workshops of the wellknown business speakers.

Statistics of requests in Yandex. The umbrella descriptor "Higher education online" had over 2 thousand impressions per month in 2017. It included the following keywords: "higher education online" (impressions per month - 25546); "distancelearning higher educational institution" (12506); "distance learning higher education" (7470); "distance education based on the higher one" (4627); "state distance higher education" (3329); "higher educational institutions distance 
higher education" (3203); "higher education online at a state higher educational institution" (2518); "get higher education online" (2230) (Goncharova et al., 2018).

Alongside this, minimum requests are observed in Yandex. Keywords selection system for the descriptors "higher education degree online": "higher education degree online" (impressions per month - 366); "distance higher education state diploma" (185); "distance higher education state degree" (155); "higher education diploma online" (77); "get distance higher education degree" (35); "higher education online state dipl." (33); "diploma of higher education by distance learning" (25); "get a diploma of higher education quickly online" (7) (Goncharova et al., 2018).

The obtained data may be indicative of a reduced level of trust in such a form of getting higher education: the quality of training, recognition of the diploma in the labor market, etc. raise doubts.

For analyzing the market of distance educational services, the selection included only the higher educational institutions of Moscow region that allowed getting a bachelor's degree online. We took into account the ratings of higher educational institutions of the independent "Vuzoteka" [Collection of Russian universities] portal and the "National rating of universities" for 2017. We also considered the form of learning (budget-funded or fee-paying).

The Vuzoteka [Collection of Russian universities] portal gathers information about higher education institutions within one resource. The website features a ramified search algorithm for universities in all regions, cities, and towns of the Russian Federation. We adopted the following criteria as the rating basis: the average USE score for admission, the quality of student hostels provided, and being in demand with employers. The information is provided both by the higher educational institutions themselves and by the third-party organizations. The target audience of the resource is the applicants. Its rating currently covers over 2300 higher educational institutions of Russia, branches included.

The National rating of universities is a dedicated project of Interfax Group launched in 2009 to develop and test out new mechanisms of an independent assessment system for the Russian higher educational institutions. At the beginning stage, the Federal Education and Science Supervision Service supported the project; since 2010, it has been implemented as the own project of Interfax with the Echo of Moscow radio station participating. Currently, it covers over 320 higher educational institutions of Russia. The obtained results are in Table 2 below. 
Table 2: Popularity of universities in the Moscow region (descriptor counts) among Runet [Russian network] users

\begin{tabular}{|c|c|c|c|c|}
\hline $\begin{array}{l}\text { HIGHER EDUCATIONAL } \\
\text { INSTITUTION }\end{array}$ & $\begin{array}{c}\text { Position in the } \\
\text { Vuzoteka } \\
\text { [Collection of } \\
\text { Russian } \\
\text { universities] rating }\end{array}$ & $\begin{array}{l}\text { Position in the } \\
\text { National rating of } \\
\text { universities }\end{array}$ & Form of learning & $\begin{array}{l}\text { Impressions } \\
\text { per month }\end{array}$ \\
\hline $\begin{array}{l}\text { Financial University under the } \\
\text { Government of the RF }\end{array}$ & 12 & 29 & fee-paying & 148 \\
\hline $\begin{array}{l}\text { Moscow State University of } \\
\text { Construction }\end{array}$ & 23 & 55 & fee-paying & 211 \\
\hline \begin{tabular}{|l} 
NRI "Moscow Power \\
Engineering Institute"
\end{tabular} & 29 & 68 & fee-paying & 314 \\
\hline $\begin{array}{l}\text { G. V. Plekhanov Russian } \\
\text { University of Economics }\end{array}$ & 43 & 53 & fee-paying & 116 \\
\hline $\begin{array}{l}\text { Moscow Institute of Electronic } \\
\text { Technology } \\
\text { NRI MIET }\end{array}$ & 49 & 28 & fee-paying & 20 \\
\hline $\begin{array}{l}\text { Russian State University for } \\
\text { the Humanities }\end{array}$ & 65 & 107 & fee-paying & 2033 \\
\hline $\begin{array}{l}\text { NEI "Moscow Technological } \\
\text { Institute" (World } \\
\text { Technological University) }\end{array}$ & 83 & 139 & fee-paying & 115 \\
\hline Russian State Social university & 86 & 63 & fee-paying & 396 \\
\hline $\begin{array}{l}\text { Moscow State Psychological } \\
\text { and Pedagogical University }\end{array}$ & 107 & & $\begin{array}{c}\text { budget-funded, } \\
\text { fee-paying }\end{array}$ & 197 \\
\hline Russian New University & 134 & 91 & fee-paying & 120 \\
\hline $\begin{array}{l}\text { Moscow State University of } \\
\text { Geodesy and Cartography }\end{array}$ & 200 & 217 & fee-paying & 97 \\
\hline $\begin{array}{l}\text { International Institute of } \\
\text { Economics and Law (NEI IIEL) }\end{array}$ & 349 & & fee-paying & 159 \\
\hline Dubna State University & 369 & & fee-paying & 97 \\
\hline $\begin{array}{l}\text { Russian University of } \\
\text { Cooperation }\end{array}$ & 398 & & fee-paying & 63 \\
\hline Synergy MFIU & 987 & 227 & fee-paying & 3175 \\
\hline $\begin{array}{l}\text { S. Yu. Witte Moscow } \\
\text { University }\end{array}$ & 1093 & 209 & fee-paying & 683 \\
\hline $\begin{array}{l}\text { International Independent } \\
\text { University of Environmental } \\
\text { and Political Sciences } \\
\text { (Academy IIUEPS) }\end{array}$ & 1217 & & fee-paying & 7 \\
\hline $\begin{array}{l}\text { International Law Institute } \\
\text { (Moscow) }\end{array}$ & 1231 & & fee-paying & 35 \\
\hline $\begin{array}{l}\text { Moscow University of Finance } \\
\text { and Law }\end{array}$ & 1284 & & fee-paying & 15 \\
\hline $\begin{array}{l}\text { Institute of International Trade } \\
\text { and Law }\end{array}$ & 1294 & & fee-paying & 4 \\
\hline Institute of World Civilizations & 1388 & & fee-paying & 67 \\
\hline $\begin{array}{l}\text { Moscow Institute of State } \\
\text { Management and Law } \\
\text { (MISML) }\end{array}$ & 1769 & & fee-paying & 2 \\
\hline
\end{tabular}

Source: authors based on Goncharova et al., 2018. 
Not all the higher educational institutions of Moscow region under analysis have made it to the National rating of universities. In the evaluation of higher educational institutions with the option of getting a bachelor's degree online provided by the Vuzoteka [Collection of Russian universities] portal, it is only the Financial University under the Government of the RF that ranks among the top 20 universities of the Moscow region. However, they use distance learning at this higher educational institution in the extramural department, with the diplomas containing the information about it. It is only eight educational institutions of the list given above that entered the one hundred best universities of the Moscow region. In the National rating of universities, Moscow Institute of Electronic Technology and Financial University under the Government of the RF rank 28 and 29, respectively.

Notably, in the overwhelming majority of cases, training is fee-paying, with the fee of learning depending on the focus area and faculty and ranging within 40 thousand rubles and 120 thousand rubles per year. An exception is Moscow State Psychological and Pedagogical University. Here one can study as a budgetfunded student. This higher educational institution works with students having health limitations. There are distance courses at the full-time and part-time department specially designed for them.

According to the quantity of Yandex requests, the leading position is shared by Synergy MFIU and the Russian State University for the Humanities - ranking 987 and 65 in the Vuzoteka [Collection of Russian universities] portal rating, and 227 and 107 in the National rating, respectively (Goncharova et al., 2018).

\subsection{The Use of Social Networks for Improving the Efficiency of Training in Mathematics}

According to the quantity of Yandex requests, the leading position is shared by Synergy MFIU and the Russian State University for the Humanities - ranking 987 and 65 in the Vuzoteka [Collection of Russian universities] portal rating, and 227 and 107 in the National rating, respectively (Goncharova et al., 2018).

The VKontakte [In contact] social network contains lots of educational public groups used by young people as resources for preparing for the USE. Analyzing such resources allows finding out the main trends in distance learning as well as the formats of learning considered by the young people to be the most convenient and modern.

The search query of the word "mathematics" in the VKontakte [In contact] social network returns 10537 communities registered, among them, there are 682 "higher mathematics", 115 "use mathematics" and 320 "school mathematics". According to the number of subscribers, it is the communities dedicated to the USE that are leaders. Table 3 shows the amount of subscribers in the leading communities associated with the USE (according to the VKontakte [In contact] data, available: June 02, 2019) and the services offered by them. 
Table 3: Popularity of universities in the Moscow region (descriptor counts) among Runet [Russian network] users

\begin{tabular}{|l|c|c|c|c|}
\hline $\begin{array}{c}\text { Communities on mathematics } \\
\text { for preparing to the USE }\end{array}$ & Number of & $\begin{array}{c}\text { Scientific rigor } \\
\text { (correspondence } \\
\text { to the USE) }\end{array}$ & Navigation & Feedback \\
\hline $\begin{array}{l}\text { USE. Mathematics } \\
\text { https://vk.com/ege_matn }\end{array}$ & 209533 & $\begin{array}{c}\text { Entertaining and } \\
\text { informative } \\
\text { content }\end{array}$ & $\begin{array}{c}\text { Specified, } \\
\text { none in fact }\end{array}$ & yes \\
\hline $\begin{array}{l}\text { USE Mathematics 100POINTS } \\
\text { https://vk.com/math_100 }\end{array}$ & 164429 & yes & yes & yes \\
\hline $\begin{array}{l}\text { USE BSE Mathematics } \\
\text { https://vk.com/egeoge_math }\end{array}$ & 117474 & yes & yes & no \\
\hline $\begin{array}{l}\text { USE BSE I Mathematics } \\
\text { https://vk.com/oge_ege_mate } \\
\text { matika }\end{array}$ & 100180 & yes & yes & yes \\
\hline
\end{tabular}

Source: authors based on Goncharova et al., 2019.

For comparison purposes, there are 117672 members registered in the top popular community "Higher mathematics" and 542 members - in "Solving problems and sums of school mathematics" (according to the VKontakte [In contact] data, available: June 02, 2019). On the whole, this picture is easy to explain: not everyone needs higher mathematics, while the USE in mathematics has to be passed by every graduate of secondary school. On the other hand, the standard allocates a particular time for mastering the general educational curriculum. Not every school teacher is ready to spend this time for the preparation for the Unified state exam (all the more so as the Federal State Educational Standard does not require this task). So the burden of responsibility is out for the students to bear. The first thing the children do is trying to solve the problem using the social network that has helped them out quite a few times.

When selecting a community, subscribers unconsciously rely on the main academic principles. These include scientific integrity, accessibility, visibility, universality and continuity, awareness (independence), systematic character and consistency, differentiation, and individualization. They look for a practical focus of training, as well as the leading principle of distance learning - the feedback available. Alongside this, the entertaining content (memes) is essential to lighten the atmosphere when studying for the exam.

For further analysis, the public "USE mathematics 100 points" was selected. Using the Popsters analytical service, the 2018-2019 academic years have been analyzed for the involvement of subscribers, identification of the most popular content, etc. according to semesters of the academic year (Goncharova et al., 2019).

The number of views was four times higher in the second half of the year as compared to the first one. Therefore, the nearer the exam is, the higher the activity is. The ER post indicator allows estimating both the involvement for the entire page and the subscribers' involvement for each post. It shows the 
percentage of users who were active in publications, and we calculate it according to the formula:

$E R$ post $=($ likes + reposts + comments $[+$ dislikes for YouTube] $) /$ the quantity of subscribers,

where the parameter "likes + reposts + comments" is the amount of registered cases of Internet users' (subscribers) activity; the parameter "dislikes for YouTube" stands for the amount of registered cases of marking this option at the YouTube service; and the parameter "the quantity of subscribers" is the total number of active users.

The ER post of the entire page equals 0,03 in the second half of the year, which is slightly higher than the value of the first one (Goncharova et al., 2019). This figure means the average involvement of participants for the VKontakte public groups. One can use the same indicator to spot the most exciting and attractive types of content. In particular, for the period from 01/01/2019 up to 02/06/2019, two kinds of material were combined: the educational one (useful formulas, explanation of problems, cribs) and the engaging one (memes about the USE in mathematics and the preparation for it). Judging by the ER post indicator, it was the entertaining content published in the last week before the exam that has been the most popular with school students. However, if we consider the same indicator for March or February, it was the educational content that was more in demand. The school students asked their questions as for an explanation of certain task types and gave more likes for the posts citing useful materials (cribs, formulas, ready solutions, etc.).

The analysis of this public group shows the opposite in the first half of the year. Then, the educational content won the highest involvement, i.e., a more conscious target audience got subscribed to this community from the beginning of the academic year. The school students are trying to study the new material extensively and save useful information to use these resources for revising in the future. In several days before the exam, subscribers respond to memes more, which may mean their readiness for the exam or, on the contrary, general fatigue.

If we compare only the educational posts, the second half of the year featured higher involvement, which is indicative of higher activity in the group during the period before exams.

The primary target audience of the public group is students of grades 10-11 of the secondary school. In the public group, all assignments are covered and reviewed from the start. They also explain all kinds of tasks in detail. The administrators of the community answer all questions of the children. The feedback is well organized, and there is extensive reference material provided.

Concerning the structure, here, all available content types are used. For example, they create photo albums that contain various kinds of tasks (a picture of the problem accompanied by a picture of the solution). So it is simpler for school students to search for the required information. Moreover, in group discussions, they give reviews of the previous years' actual USE variants. Using the group 
navigation, one can find theoretical material both for advanced and basic mathematics; browsing through all kinds of tasks for the advanced and basic USE is also available.

In general, we note the following:

1) the highest popularity in the VKontakte [In contact] social network is enjoyed by the communities on mathematics for preparation to the Unified state exam;

2) their primary target audience is school students of grades 10-11;

3) it is communities adhering to the chief academic principles that have the highest quantity of subscribers;

4) a combination of educational and entertaining content attracts the subscribers;

5) the most straightforward way of accumulating and broadcasting the mathematical (symbolic) information is the photo album.

\section{Conclusion and Recommendations}

To sum up, let us note that our studies partially have limitations on generalizations related, in particular, to the author's choice of descriptor dictionaries. However, they demonstrate current trends.

A growth of interest in distance learning is traced in the Runet [Russian network] users over time, with individual seasonal drops. One can also note the citizens' interest in getting higher education with state-recognized degrees and a qualification awarded formally. However, it is very few leading universities of the country that allow getting a bachelor's degree by distance learning, with the overwhelming majority of higher education institutions working on a fee-paying basis at that.

In Russia, it is schoolchildren of grades 10-11 who use online social networks extensively for preparing for the Unified state exam, in particular, in mathematics. The users choose a specific social network depending on how much the Internet community adheres to traditional academic principles. A combination of educational and entertaining content attracts a considerably more substantial quantity of users. The photo album is the most popular form of broadcasting the mathematical (symbolic) information in social networks.

Thus, in the nearest future, the greater popularity of the use of distance forms for training both at the higher and the secondary school can be expected in Russia. However, the negative consequences of educational computerization may diminish it (Pronchev et al., 2019). In our opinion, it is this aspect that needs to be given special attention in future research.

\section{Acknowledgments}

Support for this research was provided within the Russian Foundation for Basic Research (grant № 17-01-00390-a). 


\section{References}

Bell, D. (1973). The Coming of Post-Industrial Society: A Venture of Social Forecasting. N.Y.: Basic Books.

Bell, D. (1980). The Social Framework of the Information Society. In T. Forester (Ed.), The Microelectronics Revolution. Oxford: Blackwell, pp. 71-75.

Castells, M. (1996). The Rise of the Network Society. The Information Age: Economy, Society, and Culture (Vol. I). Malden, MA; Oxford, UK: Blackwell.

Chigisheva, O. (2018). Functional literacy: Terminological ambiguity in the worldwide educational context. Astra Salvensis, 6, 963-970.

Dillenbourg, P. (2016). The Evolution of Research on Digital Education. International Journal of Artificial Intelligence in Education, 26(2), 544-560. doi:10.1007/s40593016-0106-z

Federal Law No. 273-FL of 29 December 2012. On education in the Russian Federation. (2012). Rossiyskaya Gazeta, 5976(303).

Fuller, R. B. (1962). Education Automation: Freeing the Scholar to Return to his Studies (Southern Illinois University occasional publication). Carbondale, Southern Illinois University Press.

Goncharova, I. V., Pronchev, G. B., Krichever, I. E., \& Pronchev, K. G. (2019). Analysis of the possibilities of using online social networking to increase the effectiveness of learning mathematics. In XV Kolmogorov Readings: a collection of articles of participants of the International scientific-practical conference dedicated to the memory of Professor M. I. Zaikina (10-13 September 2019). Arzamas: Arzamas branch of Nizhny Novgorod State University, pp. 71-75.

Goncharova, I. V., Pronchev, G. B., Pronchev, K. G., \& Krichever, E. I. (2018). The interest of the users to a remote form of education. Education and Law, 3, 271-277.

Goncharova, I. V., Pronchev, G. B., \& Tretyakova, I. V. (2017). Innovations in the field of mathematical and information training of students-sociologists in the context of globalization processes. Education and Law, 8, 241-253.

Haba, H. F., \& Dastane, O. (2019). Massive open online courses (MOOCs) Understanding online learners' preferences and experiences. International Journal of Learning, Teaching, and Educational Research. 18(8), 227 - 242. DOI: 10.26803/ijlter.18.8.14

Ilyin, I. V., \& Ursul, A. D. (2016). Education, Society, Nature: Evolutionary Approach and Global Perspectives. Moscow: Moscow University Press, 556 p.

ITU. (2018). ITU Releases 2018 Global and Regional ICT Estimates. Press Release, December 07, 2018. Retrieved June 02, 2019, from https://www.itu.int/en/mediacentre/Pages/2018-PR40.aspx.

Kirkwood, A. (2014). Teaching and learning with technology in higher education: blended and distance education needs "joined-up thinking" rather than technological determinism. Open Learning: The Journal of Open, Distance, and eLearning, 29(3), 206-221. doi:10.1080/02680513.2015.1009884

Mironov, V. V. (2019). Online and offline education: methodology and decision making. Round table materials. Problems of Modern Education, 4, 9-49.

National rating of universities (2017). Interfax. Retrieved from https:/ / academia.interfax.ru/ru/ratings/?rating=1\&year=2017\&page $=1$

Pekker, P. L. (2015). Distance learning: the experience of Moscow universities. Man and Education, 2(43), 66-71.

Petrov, A. P., \& Pronchev, G. B. (2017). Collection of empirical data for the model of dynamics of interest in a political event. In Mathematical Modeling of Social 
Processes, Vol. 19, 75-79. Moscow: Keldysh Institute of Applied Mathematics

RAS. Retrieved June 02, 2019, from http:// keldysh.ru/social/2016

Popsters (2019). Popsters. Retrieved from https:// popsters.ru

Pronchev, G. B. (2013). Remote access educational information system. In: Technology to build education systems with specified properties: Materials of III International scientific-practical conference. 12 - 13 November 2012. Moscow, 284 - 286.

Pronchev, G. B., Goncharova, I. V., Elishev, S. O., \& Khodakova, N. P. (2017).

Accessibility of virtual social environments for the visually impaired as a means for leveling out social inequality in Russia. Man in India, 97(16), 107-116.

Pronchev, G. B., Kuzmenkov, D. A., \& Proncheva, N. G. (2015). Web applications as tools for electronic presentations. Distance and Virtual Learning, 7, 31-39.

Pronchev, G. B., Monakhov, D. N., Proncheva, N. G., \& Mikhailov, A. P. (2018). Contemporary virtual social environments as a factor of social inequality emergence. Astra Salvensis, 6, 207-216.

Pronchev, G. B., Proncheva, N. G., \& Goncharova, I. V. (2019). Modern Management of Media Environment: Negative Effects for the Society of Today. Journal of Environmental Treatment Techniques, 7(4), 828-835.

Synergyonline (n.d.). Synergyonline. Retrieved from http://synergyonline.ru

Toffler, A. (1971). Future Shock. New York: Bantam.

Toffler, A. (1980). The Third Wave. New York: William Morrow and Company, Inc.

USE mathematics 100 points (n.d.). VKontakte. Retrieved from https://vk.com/math_100

VCIOM. (2018). Personal Data on the Internet: Digital Threats or Opportunities? All-Russian representative poll VCIOM September 24-25, 2018. Retrieved June 02, 2019, from http:/ /d-russia.ru/wp-

content/uploads/2018/11/personal_data_wciom_opt.pdf

VKontakte (2019). VKontakte. Retrieved from https://vk.com

Vuzoteka (2019). Vuzoteka. Retrieved from http://vuzoteka.ru

Yandex. Keywords selection. (2019). Yandex. Keywords selection. Retrieved from https://wordstat.yandex.ru 